\title{
IMPLEMENTASI MODEL PEMBELAJARAN REACT DAN TINJAUANNYA TERHADAP KEMAMPUAN KOLABORATIF MAHASISWA
}

\author{
Marhan Taufik, Siti Khoiruli Ummah*, Alfiani Athma Putri Rosyadi \\ Universitas Muhammadiyah Malang, Indonesia \\ *Email: khoiruliummah@umm.ac.id \\ *Corresponden Author
}

\begin{abstract}
ABSTRAK
Pembelajaran untuk mata kuliah pendidikan matematika yang meliputi teori belajar, perkembangan peserta didik, profesi keguruan. Selama dua tahun berturut-turut pembelajaran dilakukan dengan metode ceramah, diskusi kelompok dan penugasan berupa pengerjaan Lembar Kerja Mahasiswa (LKM). Metode ini mengakibatkan mahasiswa jarang melakukan kerja sama untuk mengingat serta memaknai dan mengimplementasikan materi melalui kegiatan microteaching. Inovasi model pembelajaran diperlukan agar mahasiswa mampu berkolaborasi untuk menyelesaikan permasalahan serta mengimplementasikan materi. Tujuan penelitian ini yaitu untuk mendeskripsikan hasil implementasi model pembelajaran REACT dan tinjauannya terhadap kemampuan kolaboratif mahasiswa melalui kegiatan observasi. Metode penelitian yang digunakan adalah deskriptif yaitu dengan data kualitatif berupa hasil implementasi model pembelajaran yang dilaksanakan sebanyak 8 kali pertemuan pada kelas Strategi Pembelajaran Matematika untuk mahasiswa Semester Kedua di Universitas Muhammadiyah Malang serta adanya peningkatan kemampuan kolaboratif mahasiswa. Kemampuan kolaboratif terlihat dari pengerjaan LKM secara berkelompok dan kerja sama dalam pembuatan desain pembelajaran matematika. Kolaborasi juga dapat terlihat dari kontribusi ide penyelesaian masalah, saran, gagasan, serta pertanyaan yang bersifat konfirmasi. Selain itu, simulasi desain pembelajaran juga merupakan bentuk kolaborasi anggota tim. Kemampuan kolaboratif terlihat paling jelas ketika tahap Experiencing, Cooperating, dan Transfering. Tahap experiencing menunjukkan mahasiswa mampu menjawab pertanyaan yang didasarkan pada pengalaman pribadi. Tahap cooperating menunjukkan mahasiswa berdiskusi aktif menyelesaikan LKM secara berkelompok. Tahap transferring menunjukkan mahasiswa bekerja sama membuat desain pembelajaran serta mensimulasikan. Dengan demikian, melalui implementasi model pembelajaran REACT, mahasiswa mampu meningkatkan kemampuan kolaboratif.
\end{abstract}

Kata-Kunci: Model Pembelajaran REACT; Kemampuan Kolaboratif; Pendidikan Matematika.

\begin{abstract}
Learning on mathematics courses education that includes learning theory, students' development, and teaching profession, was performed for two years in a row by using the method of lectures, group discussions, and assignment in the form of a worksheet. The methods caused the students rarely to do work together to memorize, interpret, and implement the material through the activities of microteaching. The innovation learning model was necessary so that students could collaborate to solve problems and implement the material. This research aimed to describe the results of the implementation of the REACT learning model and its review on the students' ability to collaborate through the activities of observation. The research method employed descriptive with qualitative data in the form of the results of the implementation of the learning model implemented on 8 meetings on the class of Strategies of Learning Mathematics for the students of the Second Semester in Universitas Muhammadiyah Malang as well as an increase in the ability of collaborative students. The students' collaborative learning can also be seen from the students' contribution on problem solving, suggestions, ideas, and questions in the form of confirmation. The design and simulation of the learning design was in the form of collaboration from team members. Students' ability on collaborative learning was clear on the stage of Experiencing, Cooperating, and Transferring. The stage of experiencing showed that students were able to answer questions based on personal experience, the stage of cooperating showed that students actively conducted discussion to complete the worksheet in groups, and the stage of transferring showed that students were working together to make learning design and its
\end{abstract}


simulation. Thus, through the implementation of REACT learning model, students could improve the ability of the collaborative learning.

Keyword: REACT Learning Model; Collaborative Ability; Matemathics Education

Copyright (c) 2020 Taufik et al This is an open access article under the $\underline{\mathrm{CC}-\mathrm{BY}}$ license

How to cite: Taufik, M., Ummah, S., \& Putri Rosyadi, A. (2020). Implementasi Model Pembelajaran React dan Tinjauannya Terhadap Kemampuan Kolaboratif Mahasiswa. JINoP (Jurnal Inovasi Pembelajaran), 6(1). doi: https://doi.org/10.22219/jinop.v6i1.10036

\section{PENDAHULUAN}

Aktivitas merupakan salah satu hal penting dalam proses belajar dan mengajar. Aktivitas merupakan kegiatan siswa baik secara visual, oral, writing, listening, mental, dan emotional (Nafiah et al., 2014). Proses ini berlangsung saat kegiatan belajar mengajar berlangsung. Kegiatan ini dapat berupa pengajuan pertanyaan, perumusan masalah, melakukan kegiatan yang ada di kelas, mengerjakan tugas (Mukminan, 2014). Aktivitas yang maksimal merupakan salah satu yang perlu disiapkan dalam menghadapi abad 21 (Jenkins, 2009; Satya, 2018)

Hasil penelitian (Wijaya, Sudjimat, \& Nyoto, 2016) menunjukkan bahwa kemampuan abad ke-21 yang dibutuhkan di dunia usaha dan dunia industri adalah: (1) keterampilan dan belajar berinovasi; (2) kehidupan dan karir; dan (3) keterampilan teknologi dan media informasi. Untuk menghadapi hal tersebut. Dalam menghadapi abad 21 ada beberapa hal yang perlu disiapkan yaitu keterampilan dalam memecahkan masalah, kemampuan berpikir kritis, kemampuan kolaboratif dan komunikasi. Kemampuan kolaboratif dalam hal ini adalah kemampuan dalam hubungan interpersonal dalam menyampaikan konsep yang sudah dipahami oleh individu (ASIK, 2015; Ningrum, 2016).

Kemampuan kolaboratif ini sendiri menurut (Direktorat Pembinaan SMA, 2018) adalah interaksi antara siswa satu dengan siswa yang lain untuk mencapai tujuan bersama. Pada mahasiswa Universitas Muhammadiyah Malang khususnya semester 3B proses kolaborasi selama ini masih berfokus pada beberapa kelompok tertentu saja. Biasanya berlangsung pada mahasiswa yang dominan sehingga proses pembelajaran tidak berlangsung secara maksimal. Hal ini berakibat kemampuan kolaboratif mahasiswa masih perlu dimaksimalkan lagi dalam proses pembelajaran.

Ada beberapa upaya dalam memaksimalkan kemampuan kolaboratif tersebut salah satunya dengan cara menentukan model pembelajaran yang sesuai (Mahmudi, 2006). REACT (Relating, Experiencing, Applying, Cooperating dan Transferring) adalah salah satu model yang merupakan bagian dari CTL yang di dalamnya terdapat lima proses penting yaitu: a) Relating : belajar dikaitkan dengan konteks pengalaman kehidupan atau pengetahuan yg diperoleh sebelumnya, b) Experiencing : Belajar ditekankan kepada penggalian (eksplorasi), penemuan (discovery) dan penciptaan (invention), c) Applying : Belajar bilamana pengetahuan dipresentasikan di dalam, d) Cooperating : Belajar melalui konteks komunikasi interpersonal, pemakaian bersama, mengaplikasikan dapat diartikan sebagai belajar untuk menerapkan dan menempatkan konsep yang sudah diperoleh dalam aktivitas pemecahan masalah atau latihan-latihan soal yang realistik, e) Transferring : 
Belajar melalui pemanfaatan pengetahuan di dalam situasi atau konteks baru (Nawas, 2018).

Salah satu komponen REACT terdapat Cooperating dimana pada tahap tersebut siswa diminta untuk melakukan komunikasi konsep yang sudah diperoleh sebelumnya dengan kelompok yang sudah dibentuk maupun dengan anggota kelompok lain (Department of Agricultural Sciences Education and Communication, 2014). Dalam cooperating, proses kolaborasi antara mahasiswa juga dapat dilihat karena mahasiswa bisa melakukan transfer ilmu sehingga dapat meningkatkan keaktifan dan proses berpikir kritis (Ningrum, 2016)

Berdasarkan latar belakang tersebut maka penulis tertarik untuk mengangkat judul Implementasi Model Pembelajaran REACT dan Tinjauannya Terhadap Kemampuan Kolaboratif Mahasiswa. Dalam hal ini tujuannya yaitu untuk mengetahui bagaimana proses implementasi model pembelajaran REACT dan tinjauannya terhadap kemampuan kolaboratif mahasiswa.

\section{METODE}

Penelitian ini dilakukan di semester 3B mahasiswa Universitas Muhammadiyah Malang tahun ajaran 2019/2020 pada matakuliah strategi pembelajaran. Instrumen penelitian yang digunakan yaitu : a) Lembar Kegiatan Mahasiswa, 2) Power Point, 3) Video Pembelajaran dan 4) Artikel Ilmiah. Untuk mengetahui bagaimana kemampuan kolaboratif mahasiswa menggunakan hasil lembar observasi dan wawancara. Lembar observasi dan wawancara sebelum diterapkan divalidasi oleh validator untuk mengetahui kevalidannya. Lembar observasi diisi selama proses pembelajaran berlangsung oleh observer. Wawancara dilakukan pada 3 orang mahasiswa dengan kategori kemampuan tinggi, sedang dan rendah yang dianggal mewakili data satu kelas.

Berdasarkan rumusan masalah dan tujuan yang telah ditetapkan, maka pendekatan yang digunakan dalam penelitian ini adalah pendekatan kualitatif dengan alasan bahwa dalam proses penelitian diutamakan pengungkapan makna dan proses pembelajaran yang dilakukan. Pembelajaran yang dimaksud adalah dengan menggunakan model REACT. Selain itu, untuk mengetahui tercapainya tujuan penelitian, peneliti membutuhkan data tentang kemampuan kolaboratif mahasiswa. Jenis penelitian yang digunakan yaitu kualtiattif deskriptif yaitu dengan mengungkapkan secara mendalam tentang proses pembelajaran dengan menggunakan model REACT dan memfokuskan pada kemampuan kolaboratif mahasiswa.

Desain penelitian yang digunakan yaitu : a) merencanakan, b) melaksanakan kegiatan, c) melakukan pengumpulan data, d) menganalisis data, e) menyajikan data dan f) menyimpulkan. Data yang digunakan adalah seluruh mahasiswa kelas 3B dan untuk memperdalam informasi diambil tiga subjek peneltian dengan kategori kemampuan tinggi, sedang dan rendah yang dianggap sudah mewakili data satu kelas tersebut. Analisis data yang digunakan yaitu membandingkan data hasil observasi dan hasil wawancara untuk mengetahui bagaimana kemampuan kolaboratif mahasiswa.

\section{HASIL DAN PEMBAHASAN}

Penelitian dilaksanakan dengan diawali dari kegiatan perencanaan. Kegiatan perencanaan dilakukan dengan melakukan observasi dan wawancara untuk menetukan permasalahan utama yang akan diteliti. Obervasi dan wawancara dilakukan dengan cara menelaah Rencana Perkuliahan Semester (RPS) untuk Mata Kuliah Strategi Pembelajaran pada perkuliahan sebelumnya. Hasil observasi menunjukkan, mata kuliah

Marhan Taufik, Siti Khoiruli Ummah, Alfiani Athma Putri Rosyadi, Implementasi Model Pembelajaran React Dan Tinjauannya Terhadap Kemampuan Kolaboratif Mahasiswa 
strategi pembelajaran didominasi oleh kajian teoritis tentang teori belajar, pendekatan pembelajaran, strategi pembelajaran, metode pembelajaran, teknik pembelajaran, model pembelajaran, dan kemampuan dasar mengajar. Keseluruhan materi disampaikan secara sistematis menggunakan pembahasan tentang definisi istilah, tokoh pencetus, jenis-jenis, karakteristik, implementasi dalam pembelajaran matematika, dan kelemahan serta kelebihan setiap jenisnya.

Hasil wawancara dengan dosen pengampu sebelumnya, menunjukkan bahwa metode perkuliahan yang dilakukan didominasi oleh metode ceramah. Metode penugasan yang dilakukan yaitu pemberian LKM untuk dikerjakan oleh kelompok kemudian dipresentasikan. Alasan dosen pengampu sebelumnya diungkapkan melalui skrip wawancara sebagai berikut:

Perkuliahan Strategi Pembelajaran merupakan dasar teori dari penyusunan Rencana Pelaksanaan Pembelajaran (RPP) yang merupakan syarat wajib kemampuan yang dimiliki oleh guru. RPP yang disusun sebaiknya mempunyai landasan teoritis dan sesuai dengan karakteristik dari setiap istilah terkait pendekatan, strategi, metode, model, dan teknik pembelajaran. Selain itu, mahasiswa juga harus mampu mempunyai kemampuan dasar mengajar sebagai bekal mereka untuk mengajar. Teori ini biasa disampaikan secara satu arah karena apabila mahasiswa mengerjakan LKM maka teori cenderung keluar dari konteksnya. Diskusi kelompok kurang berjalan optimal karena pembagian kelompok saya serahkan ke mahasiswa sehingga terdapat dominasi di beberapa anggota sehingga terlihat aktif. Diskusi klasikal yang dilakukan juga belum bisa dikatakan lancar mengingat masih banyaknya mahasiswa yang tidak menyimak teman lain yang sedang presentasi.

Berdasar pernyataan yang disampaikan oleh dosen pengampu MK Strategi Pembelajaran sebelumnya, perkuliahan lebih sering dilakukan metode ceramah dari dosen karena apabila mahasiswa yang menyampaikan terdapat ketidaksesuaian dengan teori yang disampaikan. Selain itu, diskusi kelompok belum dapat membuat setiap mahasiswa aktif menyampaikan pendapat karena tidak adanya tanggung jawab individu untuk menyelesaikan LKM. Diskusi klasikal juga disampaikan membosankan karena banyaknya mahasiswa yang asyik bermain gadget sehingga tidak memperhatikan presentator. Hal ini mempunyai pengaruh terhadap hasil belajar mahasiswa dalam bentuk Ujian Tengah Semester maupun Ujian Akhir Semester. Pengaruh tersebut yaitu mahasiswa mempunyai rata-rata skor yang tidak mencapai 80 poin.

Persepsi mahasiswa yang telah menempuh perkuliahan Strategi Pembelajaran juga ditelaah menggunakan metode wawancara. Hasil wawancara tersebut yaitu:

Perkuliahan Strategi Pembelajaran yang telah saya ikuti pada 2 semester lalu tidak dapat saya pahami secara keseluruhan. Hal ini dikarenakan metode pembelajaran dosen yang digunakan membosankan. Kami diminta mengerjakan LKM ketika dosen sudah masuk kelas tanpa bahan ajar yang diarahkan untuk kami jadikan referensi. Diskusi kelompok yang saya lakukan berdasarkan mood karena saat saya berada dalam tim yang anggotanya mempunyai IPK lebih tinggi dari saya, membuat saya malas untuk bertanya, menyampaikan ide, serta berkontribusi untuk menyelesaikan LKM. Saya dan teman-teman berpendapat bahwa penyelesaian LKM tidak dianalisis skor individunya oleh dosen. Saat diskusi kelas berlangsung, saya cenderung malas mendengarkan karena penyampaian teman-teman monoton yaitu membaca LKM. Hal ini membuat saya tidak bisa mengingat materi di perkuliahan tersebut secara utuh. Hasilnya, saya kesulitan dalam mengikuti MK Perencanaan Pembelajaran. Saya tidak mampu menuliskan pendekatan, model, strategi, dan metode pada RPP saya. 
Hasil wawancara dengan mahasiswa yang pernah menempuh MK Startegi pembelajaran menunjukkan kurangnya kerja sama mahasiswa dalam penyelesaian LKM secara berkelompok. Metode diskusi dan presentasi yang dilakukan di kelas membuat mahasiswa tidak menyimak sepenuhnya. Pembelajaran dengan metode seperti yang pernah dilakukan tersebut tidak membawa hasil belajar yang memuaskan mahasiswa. Mahasiswa mengaku menyesal tidak belajar dan mengikuti pembelajaran dengan baik sehingga kesulitan dalam penyusunan RPP.

Berdasar hasil observasi dan wawancara yang dilakukan, terdapat beberapa permasalahan dalam pembelajaran yaitu: 1) perkuliahan menggunakan metode yang monoton yaitu diskusi dan penugasan, 2) tidak semua mahasiswa terlibat diskusi secara aktif (menyampaikan pendapat, ide, bertanya maupun memberikan saran), 3) mahasiswa tidak antusias dalam perkuliahan, 4) belum adanya bahan ajar, 5) hasil diskusi disampaikan dengan cara membaca jawaban pada LKM, 6) rata-rata hasil belajar kelas kurang memuaskan, dan 7) mahasiswa belum mampu mengimplementasikan teori ketika membuat RPP. Permasalahan ini kemudian difokuskan pada permasalahan utama yang akan diselesaikan yaitu perlunya meningkatkan kemampuan kolaboratif mahasiswa melalui diskusi dan perlunya inovasi model pembelajaran yang membuat mahasiswa aktif berkolaborasi dalam kelompok serta membuat mahasiswa memaknai materi perkuliahan dengan baik.

Permasalahan tersebut selanjutnya dilakukan studi literatur untuk menentukan referensi yang sesuai untuk permasalahan dan dapat dijadikan solusi bagi permasalahan yang telah dirumuskan. Literatur difokuskan pada pentingnya kemampuan kolaboratif mahasiswa. Hasil studi literatur salah satunya menunjukkan bahwa interaksi dan komunikasi yang merupakan karakteristik dari kemampuan kolaboratif tidak dapat muncul ketika pembelajaran dilakukan dengan cara tradisional. Oleh sebab itu, diperlukan metode pembelajaran yang dapat mengeksplorasi kemampuan komunikasi dan interaksi antar siswa melalui model pembelajaran collaborative games (Wang, \& Mørch-storstein, 2009a). Selain itu, permasalahan yang ditemukan juga sesuai dengan penelitian Prayitno (2013) yang menyatakan bahwa model pembelajaran berbasis konstruktivis dalam bentuk REACT yang mengeliminasi kemampuan kolaboratif akan menghasilkan sintaks pembelajaran bercirikan adanya kompetisi individual. Akibatnya, siswa c enggan membagi informasi atau pengetahuan yang telah diperolehnya secara konstruktif. Hal ini berarti, terdapat kelebihan dari adanya kemampuan kolaboratif yang harus dimiliki siswa yaitu untuk membuat pembelajaran menjadi bermakna dan menghilangkan sifat kompetitif.

Studi literatur selanjutnya difokuskan pada model pembelajaran yang dapat meningkatkan kemampuan kolaboratif siswa yang diwujudkan dalam bentuk komunikasi dan interaksi. Model pembelajaran yang berpusat pada siswa salah satunya REACT (Prihandhika, 2017). Model ini dikatakan mampu untuk meningkatkan koneksi matematis yang berlangsung pada saat kegiatan Transferring. Siswa mampu mengaplikasikan teori yang diperoleh secara berkelompok dan mampu mengkoneksikan teori dalam kehidupan sehari-hari. Proses koneksi dapat berlangsung secara lancar walaupun dengan penyampaian verbal oleh setiap kelompok. Koneksi yang didasarkan pada kehidupan sehari-hari yang dialami setiap kelompok tentunya berbeda sehingga mendapatkan perhatian ketika dipresentasikan (Prihandhika, 2017). Penelitian selanjutnya yaitu model pembelajaran REACT yang digunakan mampu secara efektif meningkatkan kemampuan komunikasi matematis siswa. Siswa dapat menyampaikan pendapat secara lisan pada saat kegiatan cooperating berlangsung. Kolaborasi juga muncul pada saat siswa diminta untuk

Marhan Taufik, Siti Khoiruli Ummah, Alfiani Athma Putri Rosyadi, Implementasi Model Pembelajaran React Dan Tinjauannya Terhadap Kemampuan Kolaboratif Mahasiswa 
memberikan contoh permasalahan matematika dalam kehidupan sehari-hari untuk diselesaikan kelompok lainnya. Pembelajaran REACT membuat siswa dapat mempunyai kemampuan berpikir analitik, kritis, mengkonstruksi konsep, menyelesaikan masalah dan kemampuan berkomunikasi dengan teman, menyampaikan ide atau konsep dari berbagai sudut pandang, menggunakan pengetahuan yang dikonstruk tentang apa yang diketahui sehingga digunakan sebagai strategi awal penyelesaian permasalahan yang tidak dikenal sebelumnya. Selain itu, pembelajaran REACT bercirikan adanya kelompok-kelompok belajar untuk beraktivitas sharing-responding-communicating dengan anggota kelompok lain secara efektif (Sari Herlina, Turmudi, 2012).

Perencanaan selanjutnya yaitu membuat perangkat pembelajaran yang kemudian divalidasi oleh teman sejawat. Perangkat pembelajaran yang disusun antara lain RPP, instrument penilaian, bahan ajar, media cetak berupa LKM, dan elektronik berupa Power Point. RPP disusun menggunakan sintaks REACT dengan pendekatan saintifik. Capaian pembelajaran dan kemampuan akhir yang didapatkan diadaptasi dari silabus prodi. Instrument penilaian menggunakan lembar penilaian kualitatif dengan rubrik penilaian secara kualitatif. Bahan ajar yang disusun antara lain URL video pembelajaran dan artikel ilmiah yang bersesuaian dengan materi pokok setiap pertemuan. Media cetak berbentuk LKM dan terdapat dua macam LKM yaitu LKM untuk kelompok besar dan LKM untuk kelompok kecil. PPT yang dikembangkan memuat video pembelajaran dan sintaks pembelajaran yang harus dilakukan di kelas.

Tahapan penelitian selanjutnya yaitu pelaksanaan kegiatan. Pelaksanaan kegiatan yaitu terlaksananya pembelajaran REACT selama delapan kali pertemuan. Secara umum, materi pokok setiap pertemuan dapat dilihat pada Tabel 1.

Tabel 1. Sebaran Materi Pokok Perkuliahan Strategi Pembelajaran

\begin{tabular}{|c|c|c|}
\hline $\begin{array}{l}\text { Pertemuan } \\
\text { ke- }\end{array}$ & Materi Pokok & Kemampuan Akhir yang diharapkan \\
\hline 1 & Teori Belajar Behavioristik & $\begin{array}{l}\text { menjelaskan teori pembelajaran untuk menganalisis perbedaan } \\
\text { teori belajar Behavioristik dan implementasinya dalam } \\
\text { pembelajaran }\end{array}$ \\
\hline 2 & Teori Belajar Kognitivistik & $\begin{array}{l}\text { menjelaskan teori pembelajaran untuk menganalisis perbedaan } \\
\text { teori belajar Kognitivistik dan implementasinya dalam } \\
\text { pembelajaran }\end{array}$ \\
\hline 3 & $\begin{array}{l}\text { Teori } \\
\text { Konstruktivistik }\end{array}$ & $\begin{array}{l}\text { menjelaskan teori pembelajaran untuk menganalisis perbedaan } \\
\text { teori belajar Konstruktivistik dan implementasinya dalam } \\
\text { pembelajaran }\end{array}$ \\
\hline 4 & Teori Belajar Permainan & $\begin{array}{l}\text { menjelaskan teori pembelajaran untuk menganalisis perbedaan } \\
\text { teori belajar Permainan dan implementasinya dalam pembelajaran }\end{array}$ \\
\hline 5 & $\begin{array}{l}\text { Teori Belajar Pemrosesan } \\
\text { Informasi }\end{array}$ & $\begin{array}{l}\text { menjelaskan teori pembelajaran untuk menganalisis perbedaan } \\
\text { teori belajar Pemrosesan Informasi dan implementasinya dalam } \\
\text { pembelajaran }\end{array}$ \\
\hline 6 & Teori Belajar Humanistik & $\begin{array}{l}\text { menjelaskan teori pembelajaran untuk menganalisis perbedaan } \\
\text { teori belajar Humanistik dan implementasinya dalam } \\
\text { pembelajaran }\end{array}$ \\
\hline 7 & Teori Belajar Eksperiental & $\begin{array}{l}\text { menjelaskan teori pembelajaran untuk menganalisis perbedaan } \\
\text { teori belajar Eksperiental dan implementasinya dalam } \\
\text { pembelajaran }\end{array}$ \\
\hline 8 & $\begin{array}{l}\text { Teori Belajar Kecerdasan } \\
\text { Ganda }\end{array}$ & $\begin{array}{l}\text { menjelaskan teori pembelajaran untuk menganalisis perbedaan } \\
\text { teori belajar Kecerdasan Ganda dan implementasinya dalam } \\
\text { pembelajaran }\end{array}$ \\
\hline
\end{tabular}


Tabel 1 menunjukkan setiap pertemuan akan mempelajari teori belajar dan difokuskan pada implementasinya pada pembelajaran matematika. Setiap pertemuan, mahasiswa diminta untuk menjelaskan teori belajar beserta tokoh pencetusnya dari artikel ilmiah yang disediakan oleh dosen dalam bentuk softfile. Selanjutnya, mahasiswa diminta untuk memberikan deskripsi analisis karakteristik teori belajar dalam bentuk tulisan pada setiap kolom jawaban LKM. Pertemuan kedua dan seterusnya meminta mahasiswa menelaah perbedaan teori belajar dengan yang diperoleh pada pertemuan sebelumnya. Mahasiswa diminta untuk mendesain pembelajaran yang sesuai dengan teori yang dipelajarinya. Selanjutnya, mahasiswa diminta untuk menggambarkan pada kertas plano dan mensimulasikan setiap tahapan pembelajaran.

Implementasi model pembelajaran REACT difokuskan pada tahapan relating, experiencing, applying, cooperating, dan transferring. Tahap relating dilakukan dengan cara pengamatan terhadap video pada PPT, misalnya pada URL https://youtu.be/aGppQRLtvg. Video tersebut menayangkan contoh pembelajaran matematika yang menekankan pada karakteristik teori behavioristik. Mahasiswa diminta menyimak dan diperbolehkan menyiapkan catatan dari hasil pengamatannya. Kegiatan ini sesuai dengan karakteristik kegiatan relating pada model REACT yaitu adanya aktivitas mengaitkan pengetahuan baru dan menyesuaikannya dengan pengetahuan yang telah dimiliki sebelumnya. Kegiatan bisa dilakukan secara verbal maupun melalui tayangan video (Sari Herlina, Turmudi, 2012).

Kegiatan menyimak tayangan video berlangsung kondusif. Mahasiswa antusias menyimak dan sesekali mencatat. Mahasiswa juga terlihat menanggapi dengan teman terdekatnya, misalnya "oh. perilaku si pebelajar berubah setelah diberikan treatment secara berulang-ulang". Tanggapan ini merupakan bukti bahwa mahasiswa menyimak dengan baik, dan dapat menelaah tayangan video dengan membuat hipotesis.

Tahap model pembelajaran REACT selanjutnya yaitu experiencing yang menitikberatkan pada kegiatan eksplorasi dan penemuan konsep yang dapat dilakukan secara mandiri melalui referensi yang disediakan maupun pencarian secara mandiri (Prihandhika, 2017). Kegiatan dalam penelitian ini dilaksanakan dengan posisi sudah berkelompok menjadi 4 kelompok besar yang akan membahas tokoh dan bunyi teorinya, karakteristik utama teori belajar, implementasi teori belajar dalam pembelajaran matematika dan kelebihan serta kekurangan dari implementasi teori belajar. Setiap kelompok diberikan LKM untuk diselesaikan dengan cara mencari informasi pada artikel ilmiah yang disediakan dosen atau video yang telah ditayangkan.

Kegiatan pencarian informasi untuk menyelesaikan LKM dapat dilakukan dengan cara membuka file artikel ilmiah. Setiap mahasiswa diberikan dua artikel ilmiah berbahasa Indonesia dan Berbahasa Inggris. Kegiatan ini mulai menunjukkan terlihatnya kemampuan kolaboratif mahasiswa yaitu penyampaian temuan konsep dari artikel yang dibaca. Dosen menginstruksikan setiap pendapat dicatat NIM yang dimiliki pada LKM. Empat kelompok yang diobservasi menunjukkan sebanyak 57\% anggota kelompok mampu berkontribusi dalam penemuan ide. Setelah dosen menginstruksikan bahwa setiap anggota kelompok bertanggung jawab untuk menyampaikan hasil diskusi kelompoknya pada kelompok barunya, mahasiswa secara otomatis berkontribusi dalam penyelesaian LKM.

Kegiatan pembelajaran REACT selanjutnya yaitu Applying. Tahap ini menekankan pada penerapan konsep yang telah diperoleh secara berkelompok atau berpasangan. Penerapan dapat berupa implementasi konsep pada kehidupan sehari-hari atau berbentuk soal (Nawas, Abu., 2018). Kegiatan pada penelitian ini ditekankan pada implementasi

Marhan Taufik, Siti Khoiruli Ummah, Alfiani Athma Putri Rosyadi, Implementasi Model Pembelajaran React Dan Tinjauannya Terhadap Kemampuan Kolaboratif Mahasiswa 
teori belajar pada pembelajaran matematika. Tahap ini juga sekaligus dirangkap dengan kegiatan cooperating dimana penerapan konsep yang telah diperoleh dianalisis secara berkelompok. Siswa sudah terbagi ke kelompok kecil yang beranggotakan 4 orang yang mewakili setiap kelompok besar sebelumnya. Setiap anggota kelompok baru ini selanjutnya mempunyai tanggung jawab menyampaikan pada anggota lainnya dan menyelesaikan LKM.

Mahasiswa berdiskusi aktif untuk menyelesaikan LKM. Temuan penelitian yaitu adanya dua metode dalam penyampaian materi pada kelompok. Metode pertama yaitu, setiap anggota kelompok diminta untuk menjelaskan hasil diskusi besar secara bergantian kemudian anggota kelompok lainnya mencatat hal penting yang disampaikan. Terdapat beberapa pertanyaan yang diajukan anggota lain, misalnya "...teori ini pencetusnya kok hanya satu? (pertanyaan) Bukankah Piaget juga mencetuskan Teori Humanistik? (sanggahan) Wah menurutku teori ini tidak bisa dilakukan di pembelajaran matematika karena tidak ada perubahan tingkah laku secara spesifik yang dapat diamati (pendapat kontra). Lhoh, perilaku apakah harus berupa aktivitas?(pertanyaan) Bagaimana dengan perilaku kognitif misalnya pengetahuan, kan pasti berubah, berarti teori ini cocok (pendapat pro)...". Kutipan komentar, pertanyaan dan sanggahan tersebut menunjukkan adanya kolaborasi mahasiswa dalam menyampaikan konsep. Kolaborasi disini berbentuk interaksi yang berwujud pro dan kontra tentang apa yang telah dibahas sebelumnya (Anantyarta \& Sari, 2017).

Metode kedua yaitu pencarian pertanyaan pada LKM yang sesuai dengan submateri setiap anggota kelompok. Pertanyaan tersebut kemudian dijawab oleh anggota kelompok yang mewakili kelompok besar. Setelah itu, anggota kelompok lain menyimak penjelasan dan menanyakan hal-hal yang kurang dimengerti. Metode kedua ini tidak memunculkan interaksi aktif berupa pendapat dan sanggahan. Dialog percakapan tentang interaksi antaranggota kelompok yaitu "...Apa itu scaffolding?(pertanyaan) Mengapa tokoh bruner juga muncul pada teori pemrosesan informasi, apakah dia sebagai tokoh utama? (pertanyaan)..."

Kegiatan applying dan cooperating selanjutnya juga masih berada pada diskusi kelompok kecil yang beranggotakan 4 orang. Kegiatan difokuskan pada pencarian informasi tentang model pembelajaran matematika yang sesuai dengan teori belajar yang dibahas. Setiap kelompok diperbolehkan mengakses internet untuk mencari jurnal sebagai referensi. Selanjutnya, setiap kelompok diminta menelaah jurnal tentang tahapan model pembelajaran yang diamati untuk dibuat desain pembelajaran dalam bentuk sketsa pada kertas plano. Setiap kelompok juga diminta untuk menyiapkan deksripsi singkat tentang penjelasan kesesuaian model pembelajaran yang ditelaah dengan teori belajar yang dibahas pada LKM. Kontribusi setiap anggota terlihat jelas pada saat pembagian tugas. Kolaborasi juga terbentuk demi penyelesaian desain pembelajaran. Adapun bentuk kolaborasi antara lain: 1) pencarian artikel, 2) perumusan sintaks model pembelajaran, 3) pembuatan sketsa tahapan pembelajaran, dan 4) perumusan deskripsi tentang kesesuaian sintaks dengan teori belajar. Temuan penelitian difokuskan pada adanya interaksi dan komunikasi aktif mahasiswa untuk menyelesaikan desain pembelajaran (Ningrum, 2016).

Tahap terakhir dari pembelajaran REACT yaitu transferring. Kegiatan ini mengharuskan mahasiswa mensimulasikan tahapan pembelajaran sesuai sintaks yang telah ditempel pada dinding dalam bentuk kertas plano. Mahasiswa secara antusias memperagakan tahapan demi tahapan model pembelajaran dengan membuat scenario pembelajaran dan skrip singkat yang diperagakan guru. Salah satu mahasiswa berperan sebagai guru dan anggota lainnya berperan sebagai siswa. Kolaborasi muncul ketika 
setiap kelompok memperagakan model pembelajaran yaitu adanya kerja sama untuk menuruti perintah anggota kelompok yang berperan sebagai guru untuk mensimulasikan game atau menjawab pertanyaan.

Keseluruhan temuan penelitian tentang kemampuan kolaboratif mahasiswa dapat dilihat pada Tabel 2.

Tabel 2 Temuan Penelitian

\begin{tabular}{|c|c|c|}
\hline $\begin{array}{l}\text { Tahapan } \\
\text { REACT }\end{array}$ & Bukti pernyataan yang menunjukkan kolaborasi & Bentuk Kolaborasi \\
\hline Relating & 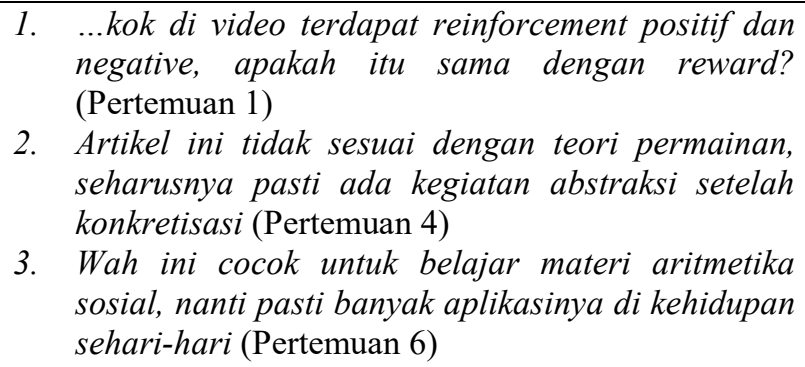 & $\begin{array}{l}\text { Pengajuan pendapat kontra } \\
\text { Pengajuan pendapat pro }\end{array}$ \\
\hline Experiencing & $\begin{array}{l}\text { 1. . ehh ini jelas beda sama behavioristic, kalo yang } \\
\text { ini siswanya tidak boleh dipaksa sama dengan } \\
\text { gurunya (Pertemuan 7) } \\
\text { 2. Menurut pendapatmu, Vygotsky yang mencetuskan } \\
\text { ZPD apakah bisa diterapkan di matematika? Kan } \\
\text { selama ini di matematika sistematika materi sudah } \\
\text { jelas (Pertemuan 3) }\end{array}$ & Pertanyaan dan tanggapan \\
\hline Applying & $\begin{array}{l}\text { 1. Berarti, kelebihan yang dimiliki behavioristic } \\
\text { merupakan kelemahan bagi konstruktivistik, benar } \\
\text { begitu atau bagaimana nih? (Pertemuan 2) } \\
\text { 2. Kalau diterapkan di matematika sepertinya cocok di } \\
\text { materi statistika. Siswa pasti memberikan contoh } \\
\text { data sesuai dengan apa yang mereka alami } \\
\text { (Pertemuan 7) } \\
\text { 3. Bagaimana ini penerapan di matematika? Apakah } \\
\text { boleh jika berupa soal? Menurutku sih tidak, kan } \\
\text { fokusnya ke pembelajaran, bukan bahan diskusi } \\
\text { yang berupa soal (Pertemuan 8) } \\
\text { Coba cari lagi model pembelajaran lain yang sesuai } \\
\text { dengan teori permainan dimana menekankan } \\
\text { adanya game pada pembelajaran. Kalau model ini } \\
\text { belum terlihat jelas (Pertemuan 4) }\end{array}$ & $\begin{array}{l}\text { Pertanyaan dan pengajuan } \\
\text { pendapat kontra } \\
\text { Pemberian saran dan } \\
\text { pengajuan pendapat kontra }\end{array}$ \\
\hline Cooperating & $\begin{array}{l}\text { Baik, kita bagi saja bagaimana? Kamu bagian mencari } \\
\text { jurnal, kamu mencatat tahapannya, nanti aku yang } \\
\text { menggambar sketsanya }\end{array}$ & $\begin{array}{l}\text { Pengajuan pendapat dan } \\
\text { pembagian tugas }\end{array}$ \\
\hline Transferring & $\begin{array}{l}\text { Ehh sketsanya kebalik urutannya, coba NG baca lagi } \\
\text { tahapannya di jurnal. Nah kan ga sesuai jadinya. } \\
\text { Bagaimana kalau ini berada pada tahapan diskusi } \\
\text { kelompok berpasangan, jadi dua orang yang berlogo } \\
\text { bintang jadi tamunya }\end{array}$ & $\begin{array}{l}\text { Pengajuan pendapat, } \\
\text { pemeberian petunjuk, } \\
\text { penyampaian informasi }\end{array}$ \\
\hline
\end{tabular}

Tabel 2 menunjukkan keberagaman bentuk kolaborasi yang muncul di setiap tahapan REACT. Secara umum, wujud dari kolaborasi mahasiswa antara lain: pemberian pendapat pro, pemberian pendapat kontra, pengajuan usulan, pemberian pertanyaan, pemberian saran, pembagian tugas dan tanggapan. Hal ini menjadikan wujud dari kolaborasi mahasiswa tidak harus dalam diskusi kelompok, melainkan dalam bentuk

Marhan Taufik, Siti Khoiruli Ummah, Alfiani Athma Putri Rosyadi, Implementasi Model Pembelajaran React Dan Tinjauannya Terhadap Kemampuan Kolaboratif Mahasiswa 
simulasi model pembelajaran. Hal ini berbeda dengan penelitian Asik (2015) yang menghsailkan kemampuan kolaboratif dalam penyusunan karya tulis ilmiah. Penelitian ini menghasilkan komunikasi verbal yang diwujudkan dalam bentuk simulasi pembelajaran. Hasil penelitian sejalan dengan penelitian sebelumnya yang menyatakan secara umum kemampuan kolaboratif diwujudkan dalam dua kelompok yaitu interaksi dan komunikasi (Ali Mahmudi, 2006; Ningrum, 2016; Wang, Øfsdahl, \& Mørchstorstein, 2009b). Kebaruan temuan penelitian ini ditekankan pada penjabaran aspek kemampuan kolaboratif yaitu pengajuan pendapat yang dibedakan menjadi pendapat pro dan pendapat yang kontra. Hal ini belum dijabarkan pada penelitian sebelumnya secara spesifik.

Temuan penelitian lain lebih difokuskan pada keterlaksanaan pembelajaran REACT dengan metode diskusi kelompok besar, diskusi kelompok kecil, presentasi kelompok, dan adanya simulasi. Hal ini berbeda dengan hasil penelitian (Nawas, Abu., 2018; Sari Herlina, Turmudi, 2012) yang menerapkan metode diskusi kelompok besar dan presentasi klasikal. Kolaboratif semakin terlihat apabila mahasiswa mempunyai tanggung jawab individu, dalam hal ini penyampaian hasil diskusi kelompok besar kepada kelompok kecil. Selain itu, presentasi klasikal diwujudkan dalam bentuk simulasi model pembelajaran. Hal ini juga merupakan temuan penelitian yang berbeda dengan penelitian sebelumnya yang melakukan presentasi secara klasikal untuk setiap kelompok, bukan pada kelompok yang telah dipilih oleh dosen (Prihandhika, 2017; Sari Herlina, Turmudi, 2012)

\section{SIMPULAN}

Implementasi model pembelajaran REACT berjalan dengan baik. Hal ini terlihat dengan terlaksananya sintaks pembelajaran REACT secara sistematis. Tahap relating menekankan adanya kegiatan analisis karakteristik teori belajar melalui tayangan video dan telaah jurnal. Tahap experiencing dilakukan secara berkelompok untuk menyelesaikan soal pada LKM tentang analisis teori belajar, karakteristik khusus, implementasi pada pembelajaran matematika, dan kelebihan dan kelemahan teori belajar. Selanjutnya, tahap applying dan cooperating digabung karena pada saat mahasiswa mengaplikasikan teori belajar untuk membuat desain pembelajaran dilaksanakan secara berkelompok. Tahap akhir yaitu transferring menekankan pada kesesuaian simulasi model pembelajaran dengan teori belajar yang telah dibahas.

Kemampuan kolaboratif mahasiswa dapat teramati secara jelas di setiap tahapan model pembelajaran REACT. Mahasiswa mampu mengajukan pendapat, membuat pernyataan pro dan kontra, melakukan pembagian tugas, pengajuan sanggahan atas jawaban teman lainnya, dan pengajuan pertanyaan. Keseluruhan aktivitas yang menunjukkan kemampuan kolaboratif sangat dominan pada kegiatan applying dan cooperating. Saran untuk peneliti selanjutnya dapat mengimplementasikan model pembelajaran REACT dalam sub matakuliah matematika.

\section{DAFTAR PUSTAKA}

Mahmudi, A. (2006). Pembelajaran Kolaboratif. Seminar Nasional MIPA 2006.

Anantyarta, P., \& Sari, R. L. I. (2017). Keterampilan Kolaboratif dan Metakognitif melalui Multimedia berbasis Means Ends Analysis. Jurnal Biologi Dan Pembelajaran Biologi, 2(2), 33-43.

Asik, N. (2015). Peningkatan Kemampuan Menulis Karya Ilmiah Melalui Pendekatan Kolaboratif. BAHTERA: Jurnal Pendidikan Bahasa Dan Sastra. 
https://doi.org/10.21009/bahtera.142.06

Department of Agricultural Sciences Education and Communication. (2014). Contextual Teaching and Learning: What is it?

Direktorat Pembinaan SMA. (2018). Modul Pelatihan Implementasi Kurikulum 2013

SMA Tahun 2018. Modul Pelatihan Implementasi Kurikulum 2013 SMA Tahun 2018.

https://youtu.be/aGpp-QRLtvg

Jenkins, H. (2009). Confronting the Challenges of Participatory Culture: Media Education for the 21 Century. Program. https://doi.org/10.1108/eb046280

Mukminan. (2014). Tantangan Pendidikan di Abad 21. Seminar Nasional Teknologi Pendidikan.

Nafiah, Y. N., Suyanto, W., Yogyakarta, U. N., Wasonowati, R. R. T., Redjeki, T., Ariani, S. R. D., ... Pembelajaran, D. (2014). Penerapan Model Problem Based Learning (PBL) pada Pembelajaran Hukum-Hukum Dasar Kimia Ditinjau dari Aktivitas dan Hasil Belajar Siswa Kelas X IPA SMA Negeri 2 Surakarta Tahun Pelajaran 2013/2014. Jurnal Pendidikan Kimia. https://doi.org/http://dx.doi.org/10.21831/jpv.v4i1.2540.

Nawas, Abu. (2018). Contextual Teaching and Learning (CTL) Approach through REACT Strategies on Improving the Students 'Critical Thinking in Writing. International Journal of Applied Management Science.

Ningrum, P. (2016). Meningkatkan Keaktifan Dan Kemampuan Berpikir Kreatif Melalui Pembelajaran Kolaboratif Berbasis Masalah Materi Kelarutan Dan Hasil Kali Kelarutan (KSP) Siswa Kelas XI Sma Negeri 10 Semarang. Jurnal Pendidikan Sains (JPS). https://doi.org/10.26714/jps.4.1.2016.17-28

Prayitno, B. A., \& Sugiharto, B. (2013). Prototipe Model Pembelajaran KonstruktivisKolaboratif Untuk Memberdayakan Kemampuan Berpikir Kritis dan Keterampilan Proses Sains Siswa Akademik Bawah. In A. Saputra (Ed.), Proceeding Biology Education Conference (pp. 1-11). Surakarta: UNS. Retrieved from https://jurnal.uns.ac.id/prosbi/article/view/6356/5740

Prihandhika, A. (2017). Perbedaan Kemampuan Koneksi Matematis Melalui Model Pembelajaran React Dengan Model Pembelajaran Learning Cycle 5e Siswa SMKN 39 Jakarta, 1(1), 1-9.

Sari Herlina, Turmudi, J. A. D. (2012). Efektivitas Strategi REACT Dalam Upaya Peningkatan Kemampuan Komunikasi Matematis Siswa Sekolah Menengah Pertama. Jurnal Pengajaran MIPA, 17(1), 1-7.

Satya, V. E. (2018). Strategi Indonesia Menghadapi Industri 4.0. Kajian Singkat Terhadap Isu Aktual Dan Strategis Strategi Indonesia Menghadapi Industri 4.0.

Wang, A. I., Øfsdahl, T., \& Mørch-storstein, O. K. (2009a). Collaborative Learning Through Games - Characteristics, Model, and Taxonomy.

Wang, A. I., Øfsdahl, T., \& Mørch-storstein, O. K. (2009b). Collaborative Learning Through Games - Characteristics , Model, and Taxonomy. Challenges.

Wijaya, E. Y., Sudjimat, D. A., \& Nyoto, A. (2016). Transformasi Pendidikan Abad 21 Sebagai Tuntutan Pengembangan Sumber Daya Manusia di Era Globalisasi. Prosiding Seminar Nasional Pendidikan Matematika 2016. 